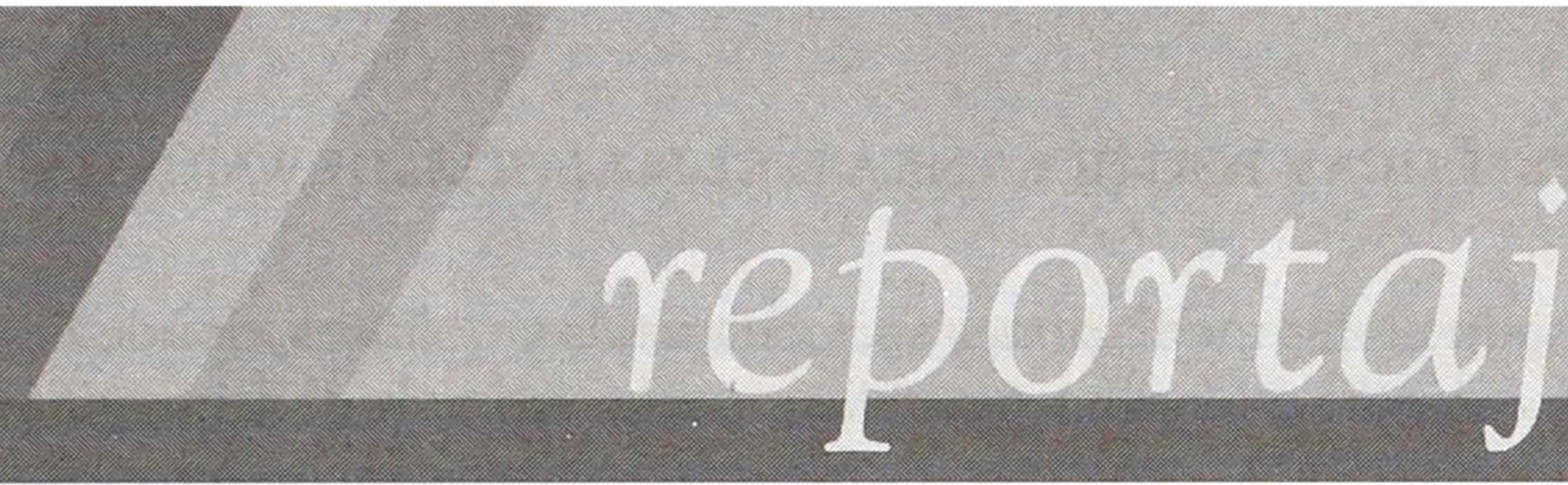

\title{
ESTETICA Y POLÍTICA EN LA ESCUELA-AYLLU DE WARISATA
}

Una aproximación al expresionismo de Mario Alejandro Illanes

Cecilia Salazar de la Torre

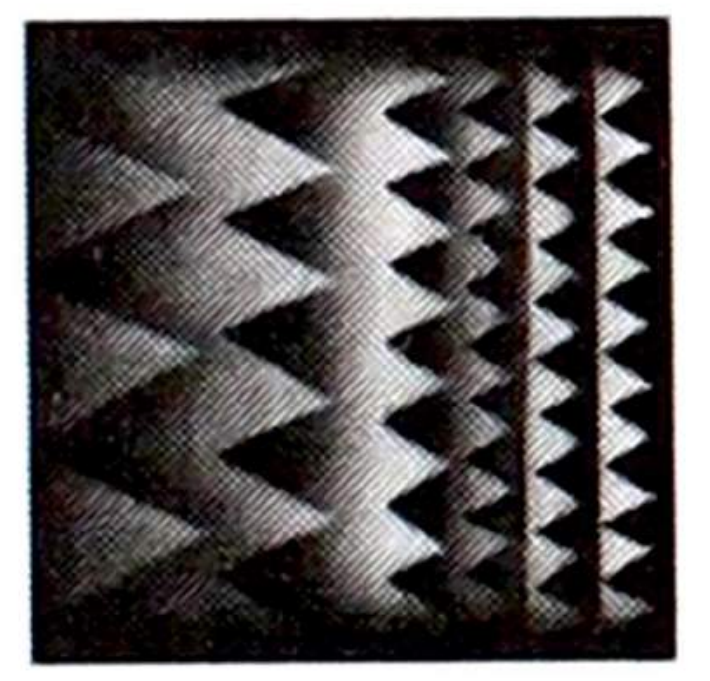

Warisatt Wawan Chamapa - „con el esfuerzo de los hijos de Warisata" - y Takke Jakken utapa - la "casa de todos»-, en lengua aymara, son las frases — del frontis de la estructura principal - con las que la Escuela-Ayllu de Warisata - la primera normal de maestros rurales de Bolivia - recibe a sus visitantes.

Fundada en 1931 - por la dupla indígena-mestiza Avelino SiñaniElizardo Pérez-, esta escuela — situada en el ambiente gris del altiplano y próxima al Lago Titicaca- albergó un proyecto de emancipación indígena al que - en aquel entonces- Frank Tannenbaum reconoció como «la más boliviana de las creaciones» (Tannenbaum, 1931).

Como tal, la Escuela-Ayllu de Warisata introdujo un paradójico proyecto educativo relativo tanto a la constitución del estado-nación 
-basado en las mediaciones socioculturales y políticas, donde tienen lugar "camaraderías horizontales» de la "comunidad imaginada" (Anderson, 1991) - como al "transcurrir de la existencia», propio de la sociedad agraria -donde la colectividad ejerce el oficio pedagógico, en el marco en el que hombres y mujeres tienen a la tierra como su "laboratorio natural»- (Gellner, 1989; Marx, 1999).

La «espléndida floración» de la Escuela-Ayllu se debía, pues, a que no buscaba violentar la mentalidad indígena ni «colocarla en una situación de estupor» y sí, en cambio, ponerla a tono con «la vida misma», de la que por primera vez el indio era «dueño y señor» (Pérez, 1934). También, a que recreaba en el horizonte de los indios una nueva disposición hacia el destino de la nación boliviana, el que -al decir de uno de ellos- sólo sería "grande» si no se olvidaba de los indios, "desparramados» a lo largo y ancho de su territorio, "sin que una luz los ilumine» (Pérez, 1934).

Edificada sobre tradiciones culturales alrededor de la organización del ayllu, su organum encontró cobijo en la ulaka o Consejo de amautas, desde donde se daba dirección a la escuela en su relación con la comunidad. Por eso también se le llamó escuela-Ayllu, pues alrededor de ella se germinó un proceso de autodeterminación que llegó a adquirir proyecciones generales, expandiéndose hacia los valles del centro del país, el sur e, incluso, hacia la selva amazónica de Bolivia (Pérez, 1962: 83).

La escuela tenía, pues, un sustrato más hondo. Por un lado, en el proyecto emancipatorio -que lleva incorporado el trabajo cuando se sostiene en la concretitud, es decir, en la relación directa entre concepto y realidad, según la cual la "subjetividad se objetiviza» y donde "la conciencia cumple un papel primario en la fijación del fin a realizar» (Lukács, 2004: 22-27)-. Por el otro, las instituciones del entorno estaban volcadas a la autoridad del pasado, encarnada en la experiencia de los más viejos - los amautas-, lo que incorporaba en su quehacer un sentimiento de identidad entre pasado y presente, propia de las sociedades prefigurativas (Mead, 1997).

Sobre esa base, Warisata concibió una forma suprema de educación basada en la escuela del trabajo productivo - la cual se autoabastece por el taller y la tierra, dejando establecido que la peculiar organización del trabajo colectivista en los Andes y sus consecuentes expresiones culturales fueron un brote de las necesidades-. Y en la que, por lo 
tanto, era impensable otra forma de vida que no fuera colectiva y no se sostuviera por la «ley del esfuerzo». Recogiendo ello, Elizardo Pérez señala:

[...] en Warisata el indio es un ser humano. En sus arcadas amplias $y$ hermosas se pasea, dueño y señor de su cultura, de su pensamiento, de su espíritu. No existe en el recinto severo más disciplina que la instituida por el voto común de sostener la obra, de vivificar la escuela (Pérez, 1934).

Por eso

[...] el indio, al realizar esta obra, no ha hecho sino obedecer sus hábitos ancestrales de trabajo cooperativo (Pérez, 1934).

Por todo ello, los conceptos que se edificaron en esta gesta no fueron producidos - para decirlo como Vallejo- en el «ingenio del bufete» 0 fuera de la vida "de carne y hueso". Lo hicieron, en cambio, en el marco de una «sensibilidad terrestre»; vale decir, en el obrar; a contrapelo de la "facundia" y del parasitismo social, de los que - según Carlos Medinaceli- se había contagiado la sociedad boliviana y que nos recuerda a la "enfermedad del habla» —aludida por Mariátegui para criticar la laxitud intelectual en el Perú - (Vallejo, 1930; Medinaceli, en Baptista, 1984; Mariátegui, 1942).

Dominado por hacendados que encontraban cobijo en el sistema leguleyo del estado gamonal, en la iglesia católica y en el ejército, el medio social y político en el que nació la escuela era profundamente hostil al indio, quien - como testimonio de aquello- llevaba inscrito - en sus espaldas sangrantes y esclavizadas - el método disciplinario del látigo. Esta relación originó el título del ensayo «La tragedia del altiplano" de Tristán Marof, en el cual este autor ubicó - en el centro del gamonalismo - el problema de la tierra, y alrededor de éste, entre otros aspectos, situó el dominio servil de la mano de obra -único modo de mantener la productividad en el medio arisco de los Andes, de clima polar y vientos helados y cortantes y donde la propiedad se justipreciaba en correspondencia directa con el número de colonos del que se disponía. Lo cual quería decir que, sin ellos, toda propiedad era pobre - (Marof, 1934). 
Esta condición alimentó la idea de que jamás ningún mestizo - «ni aún expoliado por la miseria» (Marof, 1934: 43)_fuera a trabajar las tierras del hacendado, estableciéndose una inextricable asociación entre el ocio de los propietarios y las labores forzadas de los indios; los unos, marcados por una repugnancia natural hacia el trabajo considerado como deshonroso, y los otros, reducidos corporalmente a la experiencia del esclavo. $\mathrm{O}$-como diría Negri- a la inconmensurabilidad del dolor absoluto, vivido de modo materialista (Negri, 2003). En rigor, se hacía referencia a los indios animalizando su corporeidad, lo cual restablecía la consideración de éstos como bestias de carga, "miserables y abyectas», a las cuales había que explotar "hasta la inhumanidad» (Saavedra, en Rossells, 2004: 311).

A ello debe agregarse otro argumento gamonal, según el cual el único modo de mantener al indio bajo el dominio feudal era a través de la «mano fuerte y la ignorancia». El propio Marof hace un retrato de esta postura, señalando que para el gamonal que quiere sostener una posición privilegiada, «la blandura, la sonrisa o la complacencia, son un error». Queda así demostrado, históricamente, «que la más pequeña libertad, dulzura o debilidad con los siervos acarrea desastrosas consecuencias", ya que eso podría conducir a la enajenación de su deseo de trabajar, despertándoles en el alma "derechos inadmisibles» (Marof, 1932: 45).

En este contexto, el surgimiento de la escuela-ayllu —construida y sostenida "con el esfuerzo de sus hijos»- debió ser, al menos, una afrenta. Lo excepcional fue que ésta, en el medio de su locus, puso como fuente de emancipación al propio trabajo; pasando del ciclo de la enajenación al ciclo de la autoreflexividad, es decir — siguiendo a Negri-, al descubrimiento de que «tras el derrumbe de la mesura, sólo podía sobrevenir la pasión de la creación» (Negri, 2003: 14). En este caso, puede decirse que el tránsito necesario entre opresión y emancipación encontró sentido en la tarea de recobrar la materialidad del cuerpo, «reivindicando su presencia y su resistencia» (Negri, 2003: 15). Quizá por eso, Elizardo Pérez señala que las paredes de la escuela la levantaron

[...] hombres, niños y mujeres, hurtándole minutos a la atención de la finca del patrón, sufriendo los vejámenes de éste, que se valía de toda forma para impedir el ejercicio de esta función de libertad humana (Pérez, 1934). 
Planteado el horizonte, en esta historia destaca la invocación política de la escuela-ayllu, y la apuesta por una nueva forma de «veracidad» sobre el conocimiento de lo indio. En ese plano, Elizardo Pérez (1934) hizo un planteamiento sustancial: el problema del indio es económico y, por lo tanto, los intelectuales debían dejar de lado su «falso sentimentalismo literario [...] en tesis que acobardan a la dignidad humana» (Pérez, 1934). Así, éste se asociaba a la corriente según la cual no existe "conciencia sin existencia» y que ponía en cuestión a quienes no habían tenido el valor de poner «el dedo en la pústula», y por eso «bordan sobre su miseria [la del indio] artículos, poemas y libros» (Marof, 1934: 45; Pérez, 1934).

En esta situación, todo ello apuntaba a establecer el problema de la tierra como núcleo de la opresión del indio, quien - para Pérez- «no vive, sino agoniza» (Pérez, 1934). Y ponía sobre el tapete, por lo tanto, la disputa entre hacienda y comunidad que le era propia al régimen oligárquico, cuyos argumentos pretendían justificar que el único modo de sostener la creciente demanda urbana de alimentos era a través de un sistema de productividad agrícola, racional y de amplio espectro, basado en el latifundio (Malloy, 1989).

En el fondo, ese fue el meollo a partir del cual se produjo el asedio político contra la escuela-ayllu, cuya influencia había llegado a los valles de Cochabamba y donde, al estímulo de maestros rurales, venían organizándose sindicatos campesinos y, por esa vía, tomas de tierras por la fuerza (Dandler, 1989). Junto a ello, se puso en cuestión la progresiva autonomía que iban adquiriendo los indígenas de Warisata respecto al estado gamonal, por ejemplo, para encontrar soluciones a sus conflictos intercomunitarios, tratados fuera de los formulismos leguleyos de los pueblos circundantes.

Con similar sentido, podría alegarse que el escenario de disyuntivas liberal-conservadoras también fue propicio para la discusión sobre la imagen del indio en la plástica — celebrada, algunas veces, y condenada, otras tantas-. De un lado, le daba razón a la invocación que se hiciera desde principios del siglo XX para llenar de "espíritu» a la nación boliviana; aunque, por otro, se tejiera también una disyuntiva acerca de lo que implicaba para un país "civilizado», que acababa de enfrentar la insurrección indígena de Zárate — «el temible Willka»_ en 1899, y que fue especialmente marcada por la llamada «masacre de Mohoza». 
En este contexto, habrá que recordar la vergüenza que ocasionó en los sectores más conservadores de la población el hecho de que Arturo Borda - el padre de la pintura boliviana - mostrara indígenas en su obra, en una exposición realizada en Buenos Aires, en 1919 (mencionado por Rossells, 2004).

No obstante, la invocación de Elizardo Pérez coincidía, a su vez, con la que se estaba planteando en ese entonces respecto la objetivación del indio en el plano estético, y que derivó en la disyuntiva entre "forma» $y$ «fondo». En ese campo, un primer dilema situó la imagen del indio bajo la sombra del quehacer intelectualizado, contemplativo, "frío y artificioso", o de un quehacer cargado de "emoción social». Con similar tenor, se abría campo para el establecimiento de una relación metafórica entre capacidad expresiva y desnudez; es decir, entre quienes apelando a la potencialidad de la sensibilidad "desbordada» se muestran "de cuerpo entero" y quienes, en cambio - a nombre del raciocinio atendido exclusivamente por la técnica-, anteponen la rigidez de almas que «no quieren mostrarse» (Medinaceli, en alusión a Franz Tamayo y Arturo Borda, en Medinaceli, 1978: 332).

Un segundo dilema alimentaba la discusión entre lo que con los años Javier Sanjinés llamaría la «estetización de lo político" y la "politización de lo estético» (Sanjinés, 1998), o entre un figurativismo esencial y sin arraigo histórico; por lo tanto, «esencialmente bucólico y sin peligrosidad social». El cual pone, por un lado, entre paréntesis la opresión y el conflicto agrario, apuntalando un producto carente de «verosimilitud social» (Lauer, 1997) y, por otro, un figurativismo atemperado en las condiciones de explotación del indio, que lo muestra en su condición de clase; es decir, en su carácter más ampliamente político.

En ese contexto, la obra pictórica más aclamada por los liberales fue la de Cecilio Guzmán de Rojas - considerado como uno de los hitos fundacionales de la pintura boliviana-, no sólo porque con él apareció por primera vez la figura indígena, sino porque ésta fue tratada con gran precisión y calidad técnica, al influjo de la formación académica que este artista recibió en la Escuela de San Fernando de Madrid. En su tratamiento de la relación entre figura y fondo, la obra de este artista aportó, además, con lo que posteriormente se llamaron los «ritmos voluptuosos».

Lo que hay que observar en este caso - junto a otros- es una concepción que se esfuerza por darle carácter nacional a la pintura 
boliviana, aunque con una gran carga de raciocinio. A decir de Guzmán de Rojas, "Bolivia no tiene un lenguaje artístico pictórico», por ende, es necesario que sus artistas aprendan "a hablar un idioma étnico", que es «el gran arte de Tiahuanacu» (en Rossells, 2004: 337). De igual modo, agrega:

El estilo es la nación y lo primero que debe hacer un pueblo, para tener conciencia de su nacionalidad, es descubrir y afianzar su estilo peculiar, intransferible e indesahuciable. Ese carácter propio y la conciencia de tenerlo es la raíz de su independencia, de su engrandecimiento en épocas de hegemonía y de continuidad, luego, para defenderse de ser absorbido por cualquier hegemonía foránea [...] frente a todas las peligrosas atracciones del cosmopolitismo. Esto es, sencillamente, lo que aspiro a realizar en mi obra, que si encuentra una estimación y un aliento fuera de mi país es, sin duda, porque es muy boliviana (en Rossells, 2004: 342).

Habrá que decir que Guzmán de Rojas comparte con David Crespo Gastelú, Gil Coimbra y Jorge de la Reza -entre los más destacadosla galería de los artistas indianistas, entendida como - en contraste con el indigenismo- algo similar a la estatización de lo político. En todos los casos predomina el carácter decorativo de la obra y, por lo tanto, la ausencia de planteamientos políticos alrededor del indio considerado, además, como un ser estrictamente «natural».

Sin embargo, no hay duda que estos artistas - junto a otros de menor renombre - abrieron la veta de la objetivación del indio, con el agregado que en Guzmán de Rojas aparecen —en su versión más primigenia - las tesis del elogio mestizo, las que —en el campo de la literatura - tendrían a Franz Tamayo como su más reconocido cultor -bajo los auspicios del uso metafórico del cuerpo nacional, en el que el mestizo es la cabeza y el indio la energía espiritual- (Tamayo, 1910; Sanjinés, 1999).

Por eso, el curso que siguió la polémica respecto a la obra de Guzmán de Rojas también dio cuenta del modo cómo fue reconocida y emulada después por el nacionalismo revolucionario posterior a 1952 -como ocurrió con Tamayo-, que trasladó la noción de la alianza de clases hacia la instrumentalización del mestizaje como «sobre-posición» cultural. 
Esto ocurrió a pesar de que -en su época- Guzmán de Rojas también fue objeto de críticas severas que observaban su excesiva intelectualización y, por ende, la ausencia de «emoción social». Entre aquellas estaban, por ejemplo, las del talante de las de Roberto Prudencio, para quien el artista habría ufalsificado, retorcido y forzado a la naturaleza a ser lo que no es», adulteración que sería producto «de un trabajo eminentemente intelectual, frío, calculado, artificioso y no emocional ni espontáneamente sentido, carente de pasión, de amor, de calidez anímica» y "de esa religiosa emoción que es la esencia del arte verdadero" (en Rossells, 2004: 337).

Sin lugar a dudas, estos dilemas eran objeto privilegiado del debate público, especialmente en la ciudad de La Paz, donde la polémica estaba fuertemente influenciada por La Semana Gráfica - periódico que durante varios años fue producido por los más connotados intelectuales de la época: Carlos Medinaceli, Gamaliel Churata y Francisco Villarejos (alias 'Pancho Villa'), quienes, a su vez, fueron las voces más nítidas y comprometidas con el elogio de la escuela-ayllu, a la que visitaron asiduamente y defendieron "con bravura»- (Salazar M., 2006).

En ese escenario, la otra cara de la medalla en las artes plásticas la encarnó Mario Alejandro Illanes —el muralista de la escuela-ayllu-, quien - entre otros pensadores, como Carlos Salazar Mostajo y Raúl Botelho Gosalvez - se incorporó a la planta de maestros, a solicitud de Elizardo Pérez. En su conjunto, ésta reunía a jóvenes intelectuales, varios de ellos con la experiencia trágica de la Guerra del Chaco (19321935) sobre sus hombros; conflicto que no sólo devino en un conflicto inútil entre paraguayos y bolivianos, sino que produjo entre estos últimos la sensación de haberse constituido en una "generación frustrada» y, al mismo tiempo - desde una lectura más bien nacionalista-, la que pudo dar cuenta del origen de la nación, fruto del encuentro que protagonizaron indios y criollos en el frente bélico.

Illanes nació en Oruro, el año 1913, y vivió con sus hermanos en orfanatos de esta ciudad. Empezó muy temprano a trabajar en las minas, donde fue barretero y «listero», y se compenetró, además, con la tragedia en la que se debatían los mineros. En su primera juventud, colaboró como caricaturista e ilustrador de La Semana Gráfica y, en 1934, se fue a Warisata. Pintor autodidacta, «sin escuela» (Salazar Mostajo, 1989) y forjado en la "tenacidad de un convencido" - como decía el periodista Francisco Villarejos-, Illanes fue un artista «abigarrado, truculento, 


\section{CECILIA SALAZAR DE LA TORRE}

salvaje en todo su valor primigenio", en quien algunos intelectuales saludaban el nacimiento de la "pintura aymara» (Villarejos, 1933).

Se observaba en él un intencionado esfuerzo por rechazar la lógica o el buen gusto $y$, en cambio, "por su rudeza tremenda", concitar «el odio de los observadores refinados» (Villarejos, 1933). Quizá por eso -frente a su obra-, el poeta Jaimes Freyre habría dicho: «iEste será el más grande pintor de Bolivia o el peor de todos!», mientras que Gamaliel Churata lo consideró

[...] poseedor de un formidable temperamento pictórico, de irrumpiente capacidad emotiva y de acierto temático de su mundo, aproximándose a una verdadera textura socialista» (en Rossells, 2004).

La primera obra de Illanes fue conocida en la ciudad de La Paz, donde expuso óleos sobre arpillera de gran dimensión, causando un impacto inusual en el público que - según Salazar Mostajo- veía por primera vez al indio no como motivo anecdótico, sino como el actor principal de la historia nacional, con capacidad de afrontar el rol histórico de su emancipación, esta vez a partir de la veta propiamente indigenista y politizadora.

Los murales que realizó en la escuela-ayllu muestran a indios erguidos, inmersos en sus labores, y con una dignidad que es inusual para el orden dominante. Como destaca Salazar Mostajo, son indios que no tienen tiempo para posar, por eso no están embellecidos, a no ser por la fuerza del trabajo. Los trata, pues, inmersos en su laboriosidad, aquella que deviene en una textura corporal tosca y ruda, de líneas duras en el trazo, "de corte agresivo, anguloso en la faz, casi grotesco en la forma, no sujeta a cánones ni armonías preestablecidas» (Salazar Mostajo, 1989: 80). Y, al mismo tiempo, en el contexto de una vida tranquila y en paz, con lo que reflejaba el porvenir anunciado por la escuela-ayllu.

De algún modo, la obra de Illanes expresa —en la pintura- la descripción que años atrás Churata habría hecho del indio:

Todo él, el ancho cuello y el tórax dan sensación de poder. Debajo de la camisa de cordellete parece palpitar con el propio ritmo de la entraña, el deltoides, como en la bestia fatigada. Tanta extraña conformatura está aforrada de una piel cobriza que el sol bruñe 
con sus mejores fuegos. No habla. Pero la fogata de occidente en sus últimos resplandores, orifica su perfil metálico. La tristeza de un linaje perdido en el huso se miraba en su fornido cuerpo de hambriento (Churata, 1927).

Además, el tratamiento del paisaje - «elemental y adusto como el hombre» (Salazar Mostajo, 1989) - despierta como materia vital, participando del drama humano. Su actitud con la tierra no es, pues, pasiva, sino fuertemente involucrada y, al mismo tiempo, sobria y serena, aunque arrebate una sensación de intranquilizante desbordamiento entre los receptores. Así, la tierra adquiere una presencia evidente, algo que se compenetra del indio y éste de ella, creando una unidad telúrica que tiene sentido en la apropiación mutua de la energía natural. Podría decirse - en ese sentido-que la obra de Illanes recoge la imagen del allpacamasca -sobre la que Botelho trabajaría años después en su novela Altiplano-, que le da sentido a la idea del indio como «tierra animada».

Frente a esta propuesta, queda claro que no existe disociación más trágica que la de indio sin tierra, con la que aquél establece un lazo demiúrgico (Salazar Mostajo, 1989). Y, al mismo tiempo -como diría Marof-, que no hay poeta ni doctor que venere tanto a ésta - a pesar de su «menguada entraña»- como lo hace el indio (Marof, 1932).

Ahora bien - como lo planteara Churata-, los temas tratados por Mario Alejandro Illanes son propios de una «introspección analítica». Sin embargo -como dice Salazar Mostajo-, ésta no es producto del refinamiento psicológico, sino del carácter instintivo de la obra de quien fuera conocido entre los intelectuales como «el joven cóndor». Para este autor la diferencia sustantiva entre Illanes y Guzmán de Rojas está en la capacidad de comunicación metafórica de cada uno; en el primero, la materia inerte cobra animación, al otorgarle su propia personalidad; mientras que, en el segundo, aquélla estará sometida a la técnica formal y convencional de la representación.

En ese sentido, en Illanes, la metáfora sustituye al objeto, bajo el concepto del «pensar en imágenes» y para - por un lado- revelar lo que el objeto no puede revelar y - por otro-, al hacerlo, llegar a independizar la expresión del objeto y hacerla, en sí misma, el objeto de la obra. En Guzmán de Rojas, ese logro es limitado y pobre o, en otros casos, conseguido bajo un sistema metafórico que no sustituye ni 
complementa al objeto, sino lo falsifica y lo convierte en irreal (Salazar Mostajo, 1989).

Señalado este aspecto, Illanes viene a ser -para el arte plástico boliviano- el fundador del expresionismo, entendido - hablando estilísticamente- no como un sistema de ideas, sino como un estado del alma que retrata la presión del «desorden sustantivo de las cosas y de los seres», aquél que sacude la armonía preestablecida, desajustándola a través de la "disimetría», de lo "zigzagueante», lo "zaherido», lo "desgarrado", aquello que viviendo en el interior aflora al exterior, "en su cruda verdad, maligna e implacable» (Courthion, 1968). Y que, en su curso, crea un clima angustioso y un sentido de lo grotesco, "punzante y terrible», que se subleva contra la moral burguesa a través de la deformación y la tosquedad (Hazan, 1961).

\section{III}

Kkajjañap munaptua — «que brille como el sol»—, decían los indios al contemplar la escuela que iban edificando en la altiplanicie. "Que su techo rojo alumbre a la pampa y a las montañas", decían otros (Pérez, 1962). Al calor de estas metáforas, la escuela se fue convirtiendo en el símbolo de la liberación del indio, dos décadas antes de que se produjera la Revolución de 1952, por lo que puede considerársela un antecedente de ésta.

En su proceso politizador, los maestros que estuvieron allí o culminaron su formación replicaron la experiencia en varios puntos del país, convirtiendo a los planteamientos de Warisata en una amenaza para el orden existente. Tanto fue así que el estado gamonal no encontró otro medio para destruir la escuela que destituir a sus maestros y alumnos $y$, luego, perseguirlos en nombre de la lucha anticomunista. El ciclo breve pero extraordinario en el que afloró quedó, pues, acortado a menos de una década y, desde entonces, sólo prevalece de modo alegórico en el discurso público en Bolivia, sin que nunca se haya siquiera intentado restaurarla.

Algo similar habrá que decir de Mario Alejandro Illanes, quien en una de sus últimas apariciones -en 1936-expuso su obra plástica en la ciudad de La Paz, creando una conmoción tal que el gobierno militar de entonces - encabezado por el general David Toro-, después de haber ordenado la destrucción de gran parte de su obra, lo confinó al 
trópico boliviano durante un año, considerándolo un personaje peligroso para el orden establecido. Illanes pudo salvar algunos de sus lienzos, transportándolos en un tubo de metal, durante la persecución.

Entre sus obras, se encuentra La tragedia del pongo -que alude a la escuela-ayllu-, donde la figura individual del indio cede paso a la multitud activa que arremete contra el poder, haciéndose eco de la necesidad de que "aparezca el horizonte de visibilidad general», que es "el único rescate de los hombres en su nuevo ser, que es su ser colectivo» (Zabaleta, 1988). Bajo la égida del «alma colectiva», la figura del maestro trasciende como el sujeto de la vanguardia política, mientras se recrea en la memoria la historia de opresión colonial de la que habría sido objeto el indio, y cuya continuación la encarnan personajes claramente identificables en el cuadro —como el expresidente Bautista Saavedra-.

La otra obra presentada fue Viva la guerra. Con relación a ella, sin duda, la provocáción llevaba implícita una alusión directa a la lucha de clases y la alianza obrero-campesina, sustancia del conflicto - para Illanes - que había que vivificar, en aras de la "civilización de los trabajadores». El contexto no podía ser menos propicio, en tanto Bolivia estaba intentando curarse de la herida producida por la Guerra del Chaco contra el Paraguay, de la que salió afectada territorialmente y en la que perdió 35.000 soldados. Es probable que desde el escenario de patriotismo exacerbado, la obra haya sido interpretada como un signo de la personalidad destructiva de Illanes y, sobre todo, de su ausencia de lealtad con la nación. Esto en el marco de un conflicto que marcaría el devenir de la narrativa nacionalista desde 1952, que había encontrado su cauce imaginario en el fundacional campo de batalla.

Después de una estancia de algunos meses en la cárcel, en 1941 - producto de otra exposición que turbó al alcalde de La Paz-, Illanes salió del país; primero en dirección al Perú, luego a México y, finalmente, a Estados Unidos. Su estadía en Lima fue corta, pero le permitió darse a conocer a nivel latinoamericano, siendo objeto del elogio del escritor Uriel García. En México se quedó hasta 1946, lo que le permitió conocer a los maestros del muralismo mexicano y recibir un reconocimiento público y una medalla de oro, como el gran artista de los Andes. También, trabajó con Diego Rivera -quien lo consideraba uno de los más originales pintores americanos-y colaboró con Orozco (Ruderfer, 1994). 
En 1946, emigró a Nueva York, y no se supo más de él en Bolivia, salvo que fue premiado con la beca Guggenheim para estudiar las relaciones entre el arte indio de Norteamérica y de Sudamérica. Información no precisa da cuenta que falleció en 1960, aunque otras señalan que lo habría hecho a principios de los setenta. El año 1992, la obra de Illanes fue «descubierta» entre las posesiones de la familia de Eduardo y Teresa Ford por una galería de arte de aquella ciudad que - con gran publicidad- la presentó en una muestra de gran expectativa y reconocimiento público (Ruderfer, 1994).

Como la historia de la escuela-ayllu, la de Illanes fue casi legendaria, pero olvidada por los bolivianos. Podría decirse que - en ambos casosesto se debió a la forma en la que derivó el estado-nación, atemperado por la sombra de una guerra - la del Chaco-sobre la que se apuntaló el ser boliviano, sin vislumbrar que paralelamente a ella tenía lugar en el país «la más boliviana de las creaciones», aquella que se edificó con lo que es el legado cultural más nítido y trascendente de las tradiciones indígenas: la ley del esfuerzo y, por ende, la pasión por la creación. 


\section{bibliografia}

BAPTISTA, Mariano

1984 Atrevámonos a ser bolivianos. Vida y epistolario de Carlos Medinaceli, Amigos del Libro, La Paz.

BOTELHO, Raúl

1940 Altiplano, Librería «Juventud», La Paz. (2000)

COURTHION, Pierre

1968 Introducción, en Michel Ragon, El expresionismo, Aguilar, Madrid.

CHURATA, Gamaliel

1927 «El gamonal», Amauta, núm. 5 (edición en facsímile), Amauta, Lima.

GELLNER, Ernest

1989 Naciones y nacionalismo, Alianza Editorial y Consejo Nacional para la Cultura y las Artes, México.

HAZAN, Fernando (editor)

1961 Historia ilustrada de la pintura, Gustavo Pili, Barcelona.

LUKÁCS, György

2004 Ontología del ser social. El Trabajo, Herramienta, Buenos Aires.

LAUER, Mirko

1997 Andes Imaginarios. Discursos del Indigenismo 2, Casa de Estudios del Socialismo SUR/Centro Bartolomé de las Casas, Cusco. 
MARIÁTEGUI, José Carlos

1943 Siete ensayos de interpretación de la realidad peruana, Biblioteca Amauta, Lima.

MAROF, Tristan

1932 La tragedia del altiplano, Claridad, Buenos Aires.

MARX, Carlos

1999 Formaciones económicas precapitalistas, Siglo XXI, México.

MEDINACELI, Carlos

1969 Estudios Críticos. Editorial «Los Amigos del Libro». Segunda edición. La Paz.

1978 «La personalidad y la obra de Arturo Borda», en: Chaupi P'unchaipi Tutayarka (A mediodía anocheció), obras completas de Carlos Medinaceli, selección de Carlos Castañón Barrientos, Editorial «Los Amigos del Libro», La Paz. (1937)

NEGRI, Antonio (1938)

2003 Job, la fuerza del esclavo, Paidós, Buenos Aires.

PÉREZ, Elizardo

1934 «Mensaje de la Escuela de Warisata en el Día de las Américas», La Paz.

1962 Warisata, la Escuela-Ayllu, Librería «Juventud», La Paz.

RIVERA, Silvia

2003 «El mito de la pertenencia de Bolivia al 'mundo occidental'. Réquiem para un nacionalismo", en: Medio siglo de la Revolución Nacional de 1952, Instituto de Investigaciones Sociológicas, Universidad Mayor de San Andrés.

ROSSELLS, Beatriz

2004 «Espejos y máscaras de la identidad. El discurso indigenista en las artes plásticas (1900-1950)", en Estudios Bolivianos, núm. 12, «La cultura del pre-52», Instituto de Estudios Bolivianos, CIMA, La Paz. 
RUDERFER, Betsy

1994 «Let's Bring the Illanes Collection Home», en Bolivian Times.

SALAZAR MOSTAJO, Carlos

1989 La pintura contemporánea de Bolivia. Ensayo histórico-crítico, Librería Juventud, La Paz.

2006 Gesta y fotografía. Historia de Warisata en imágenes, Lazarsa, La Paz.

SANJINÉS, Javier

1992 Literatura contemporánea y grotesco social en Bolivia, Fundación BHN/ILDIS, La Paz.

1998 "Modelos estéticos de cultura nacional», en: Tinkazos, Revista boliviana de ciencias sociales, núm. 2, diciembre, PIEB, La Paz.

1999 «Tamayo; observador: negociando lo 'letrado' con lo visual'», Conferencia inaugural de la Mesa Redonda "Propuestas y tendencias del arte plástico boliviano de los 90", Primer Salón Internacional de Arte - SIART 99, octubre, La Paz.

TAMAYO, Franz

1975 Creación de la Pedagogía Nacional, Biblioteca del Sesquicentenario de la República, La Paz. (1910)

TANNENBAUM, Frank

1939 Entrevista a Frank Tannenbaum, El Diario, 29 de julio de 1939.

VALLEJO, César

1930 "Autopsia del superrealismo», Amauta, núm. 30, edición en facsímile, Amauta, Lima.

VILLAREJOS, Francisco

1933 «Vida artística. Los pintores Reque Meruvia, Valdivia Dávila e Illanes», La Semana Gráfica, julio.

ZAVALETA, René

1988 Clases sociales y conocimiento, Los Amigos del Libro, La Paz. 


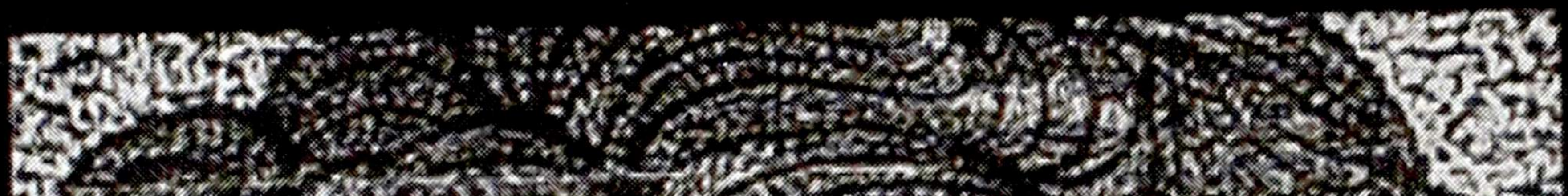

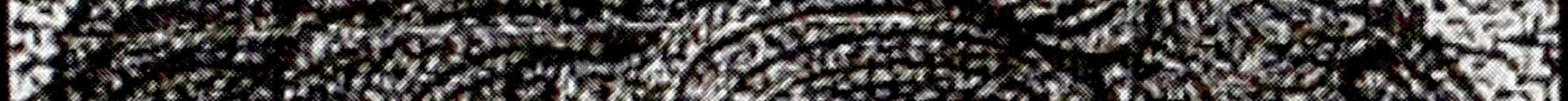
1.

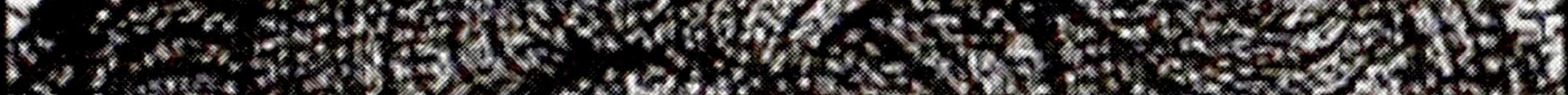

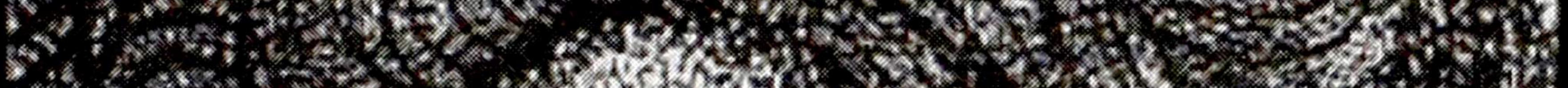

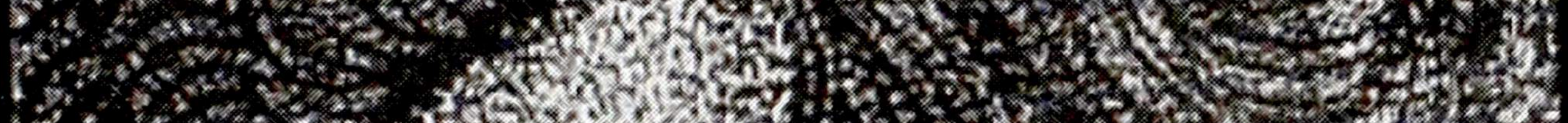

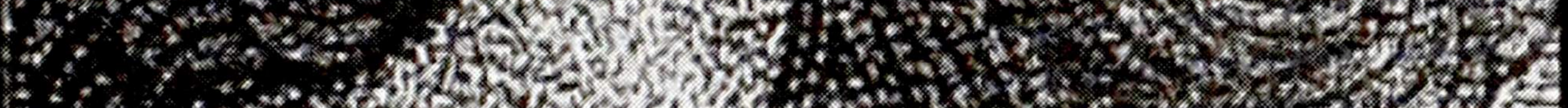
* * * * * * *

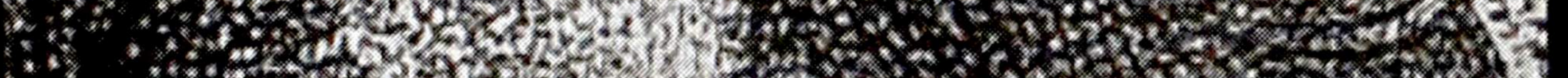
(1) 10.

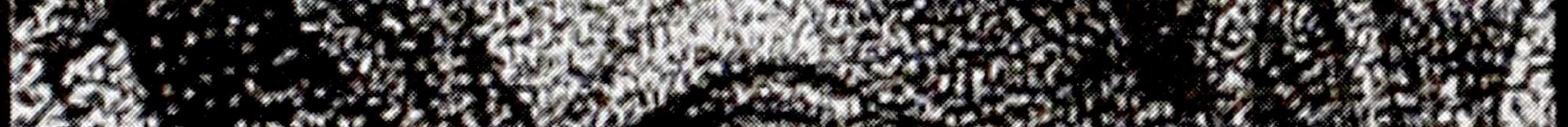

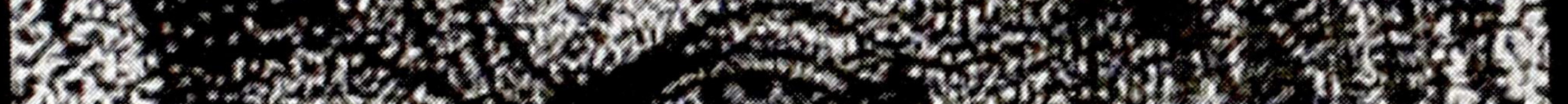

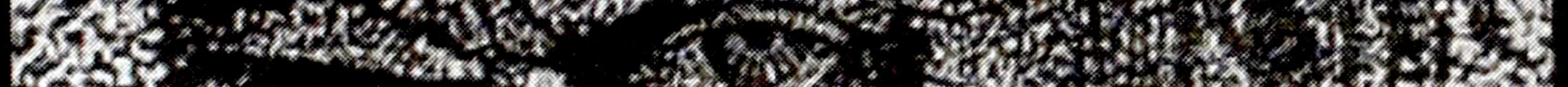
$10522^{2}$.

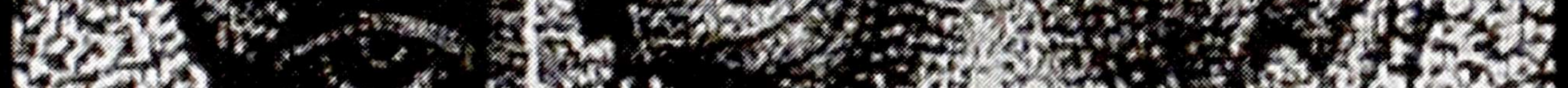

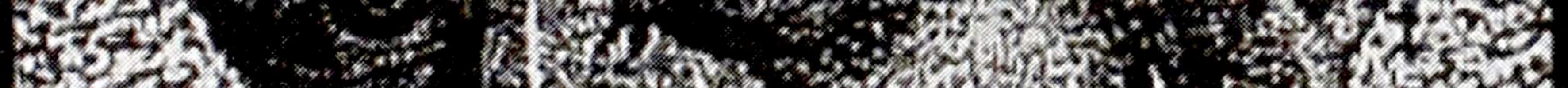

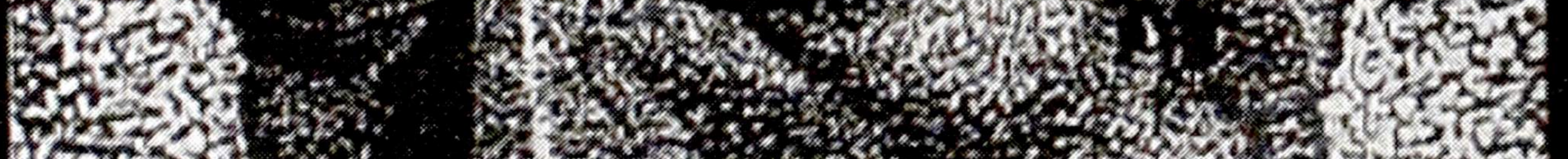

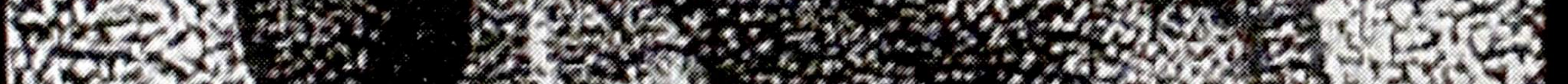

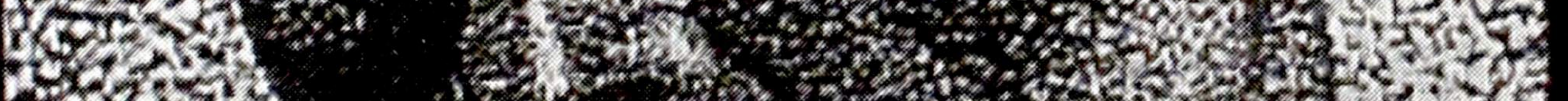

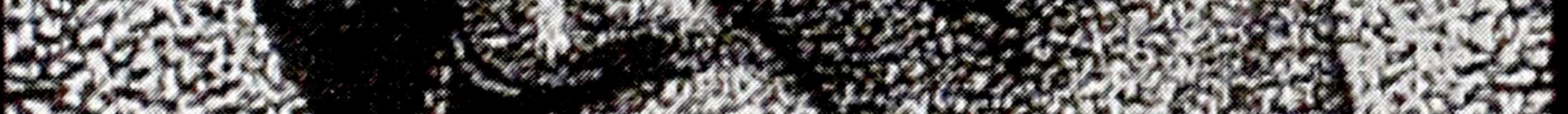

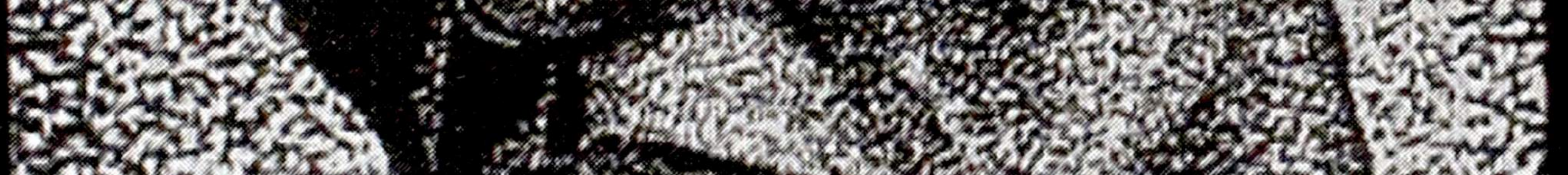
c. 63 -

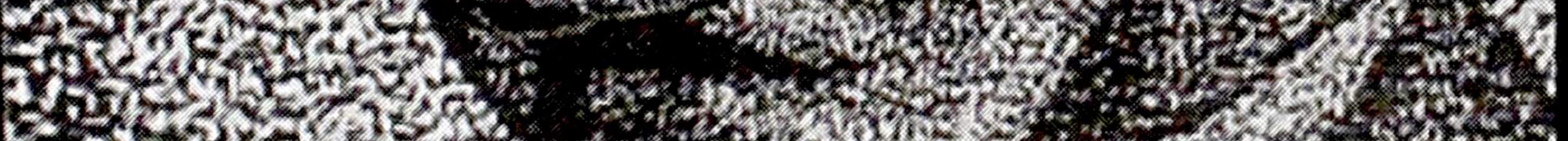

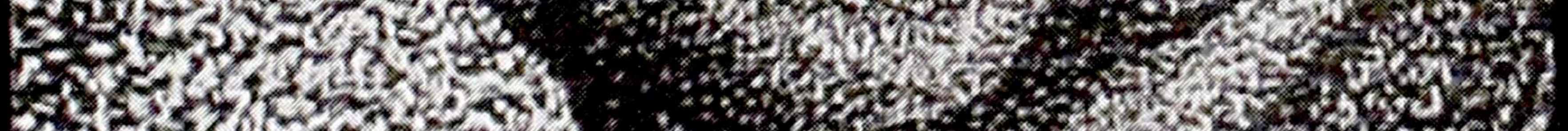

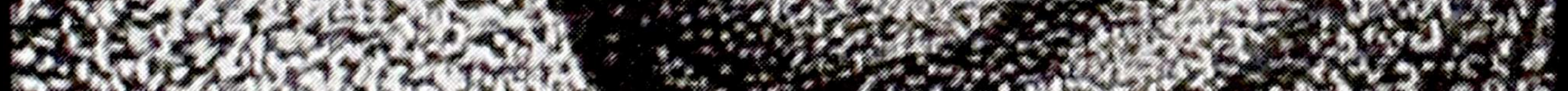
(5.2.

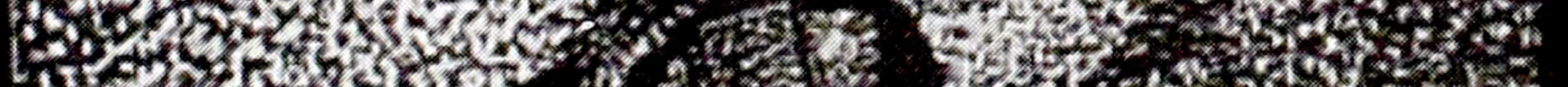

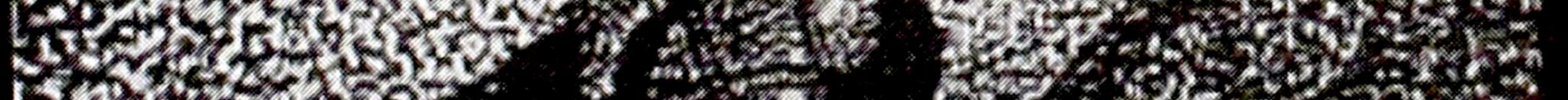

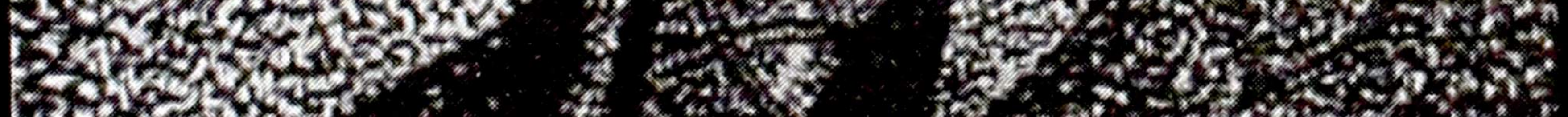

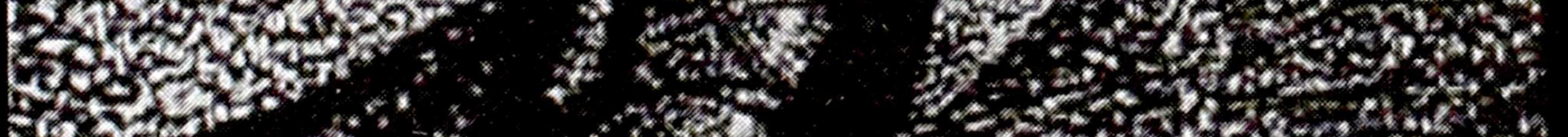

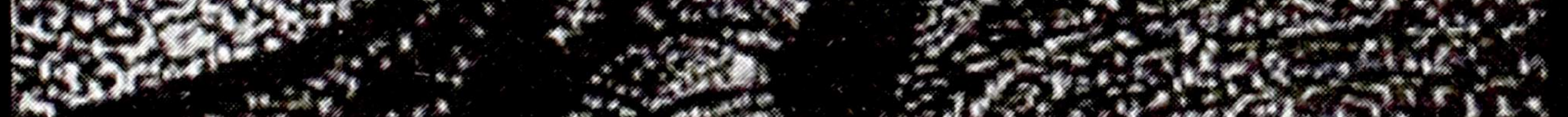

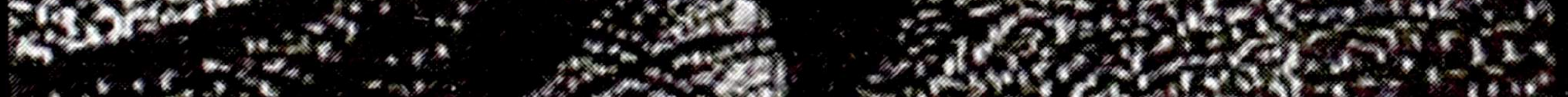

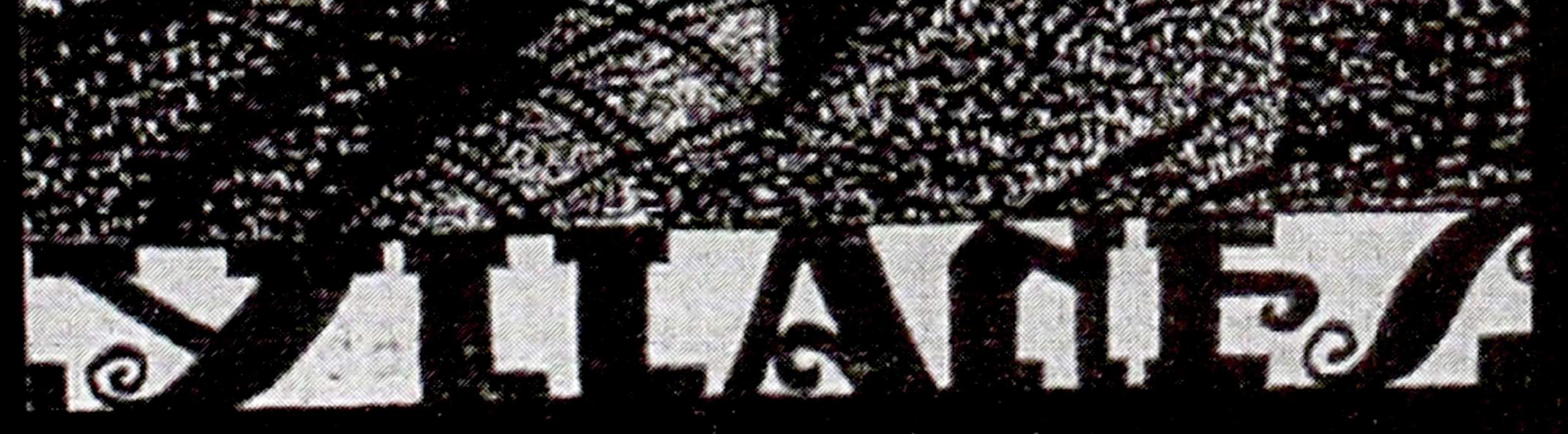




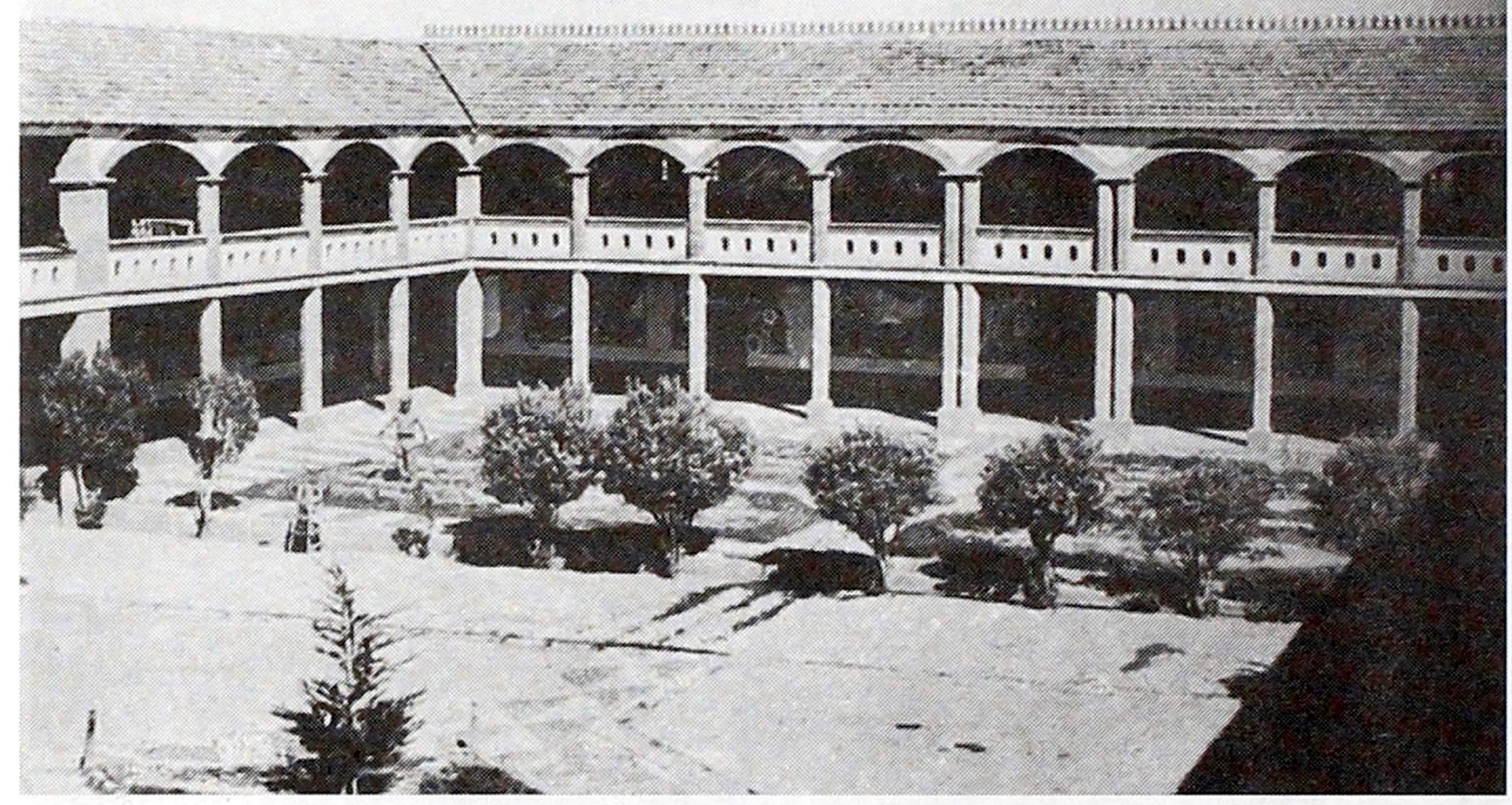

La Escuela-Ayllu (interior)

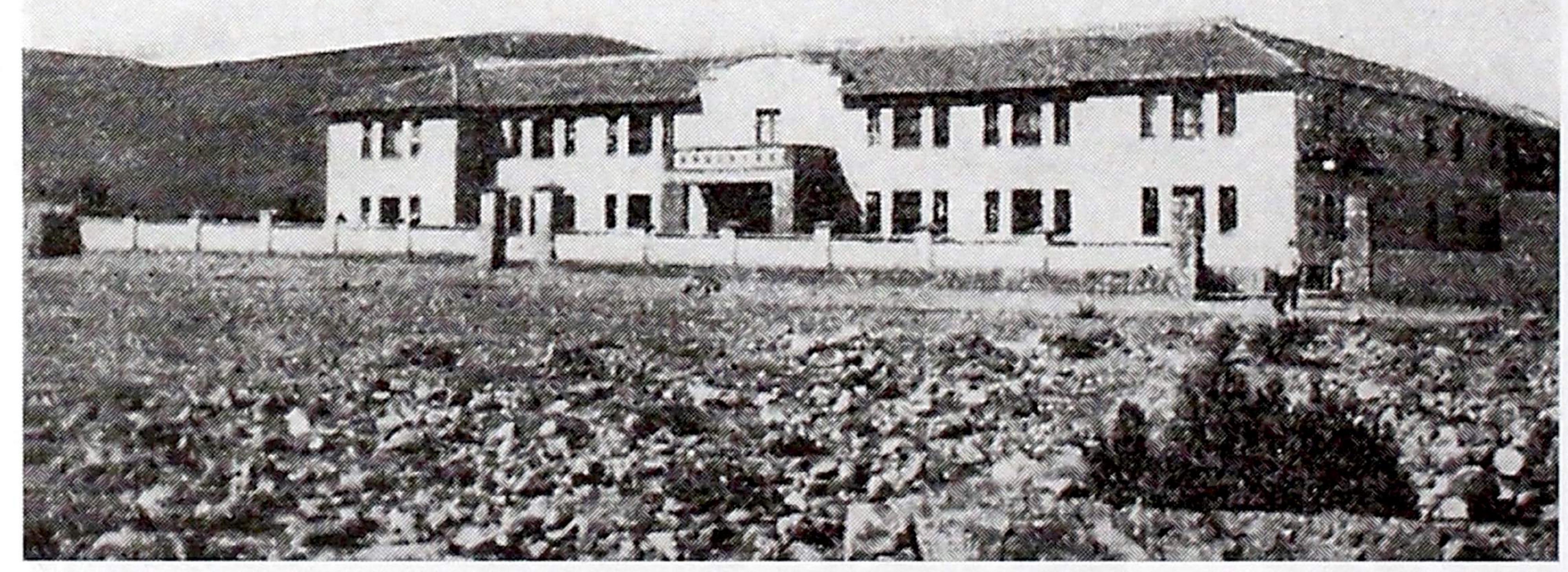

La Escuela-Ayllu (exterior) 


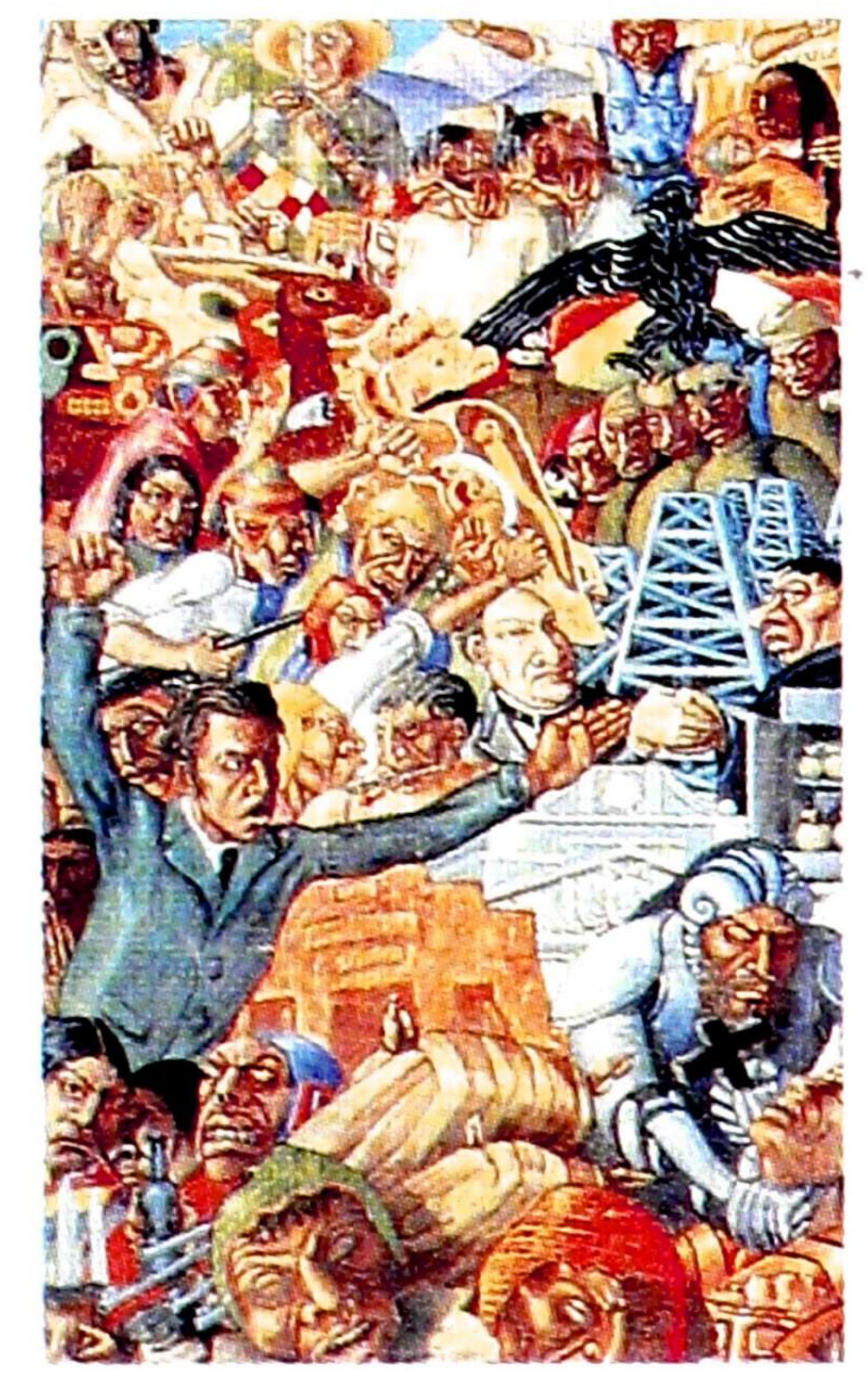

La tragedia del pongo (Illanes)

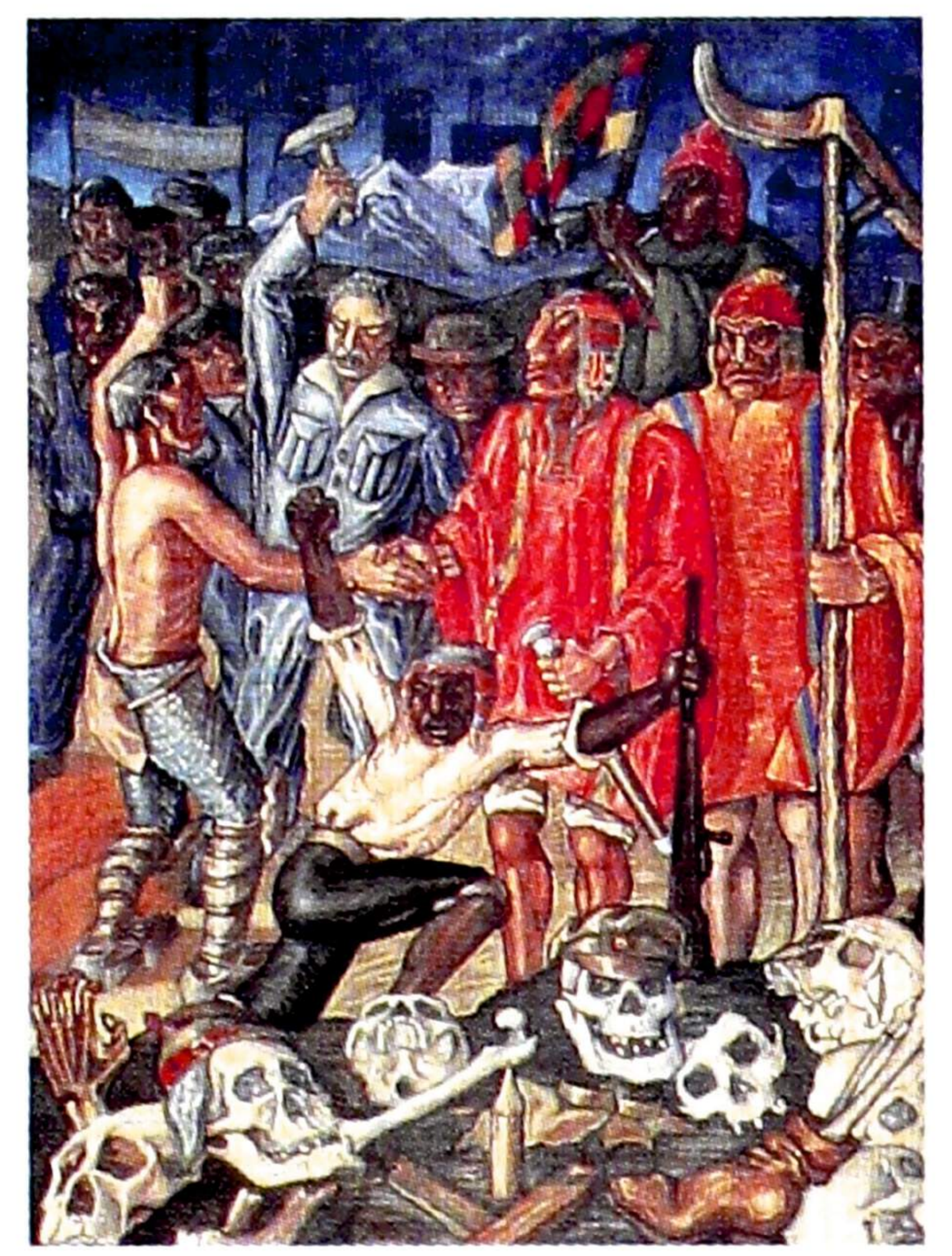

Viva la Guerra (Illanes)

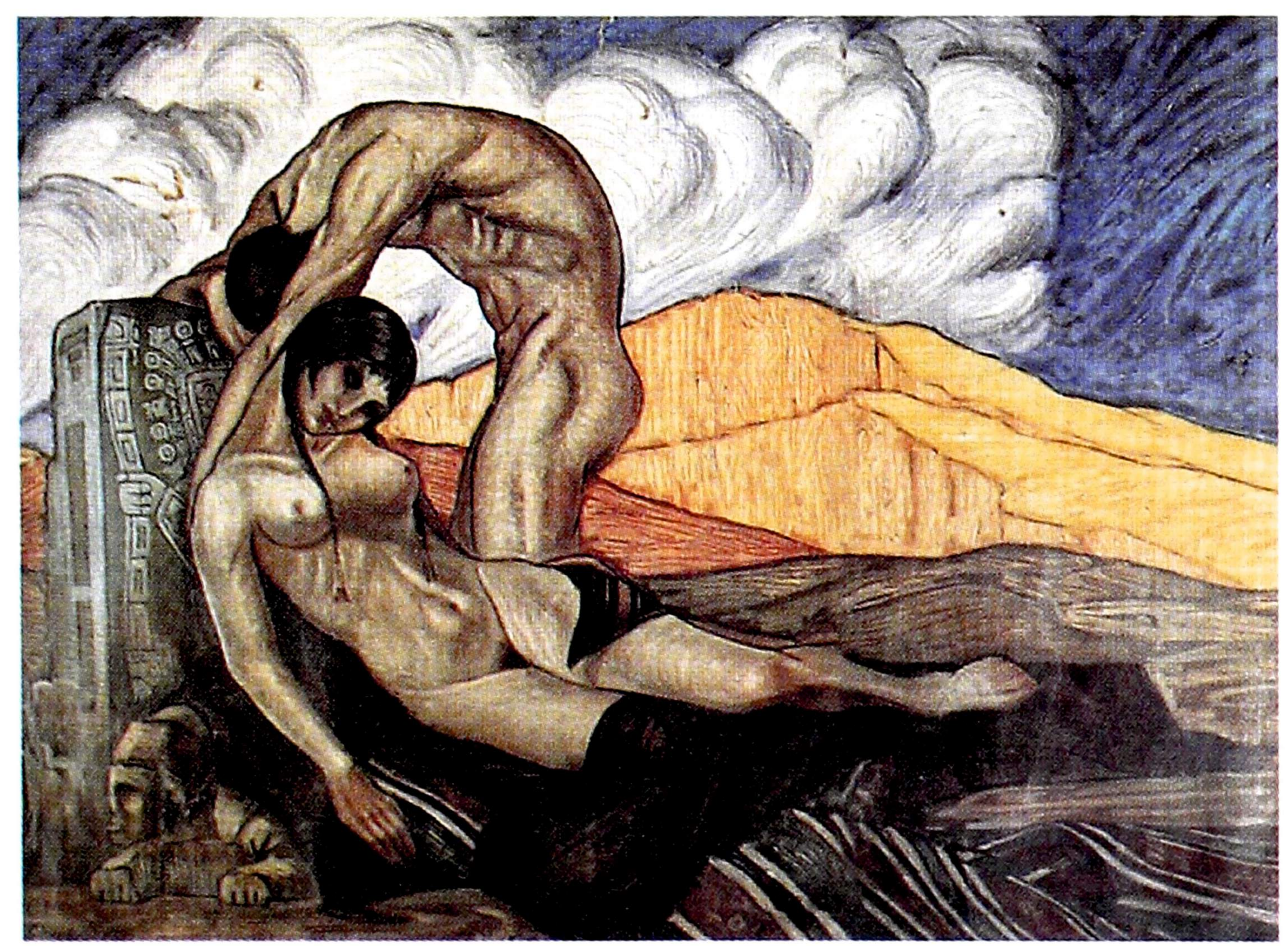

El triunfo de la naturaleza (Guzmán de Rojas, 1928) 

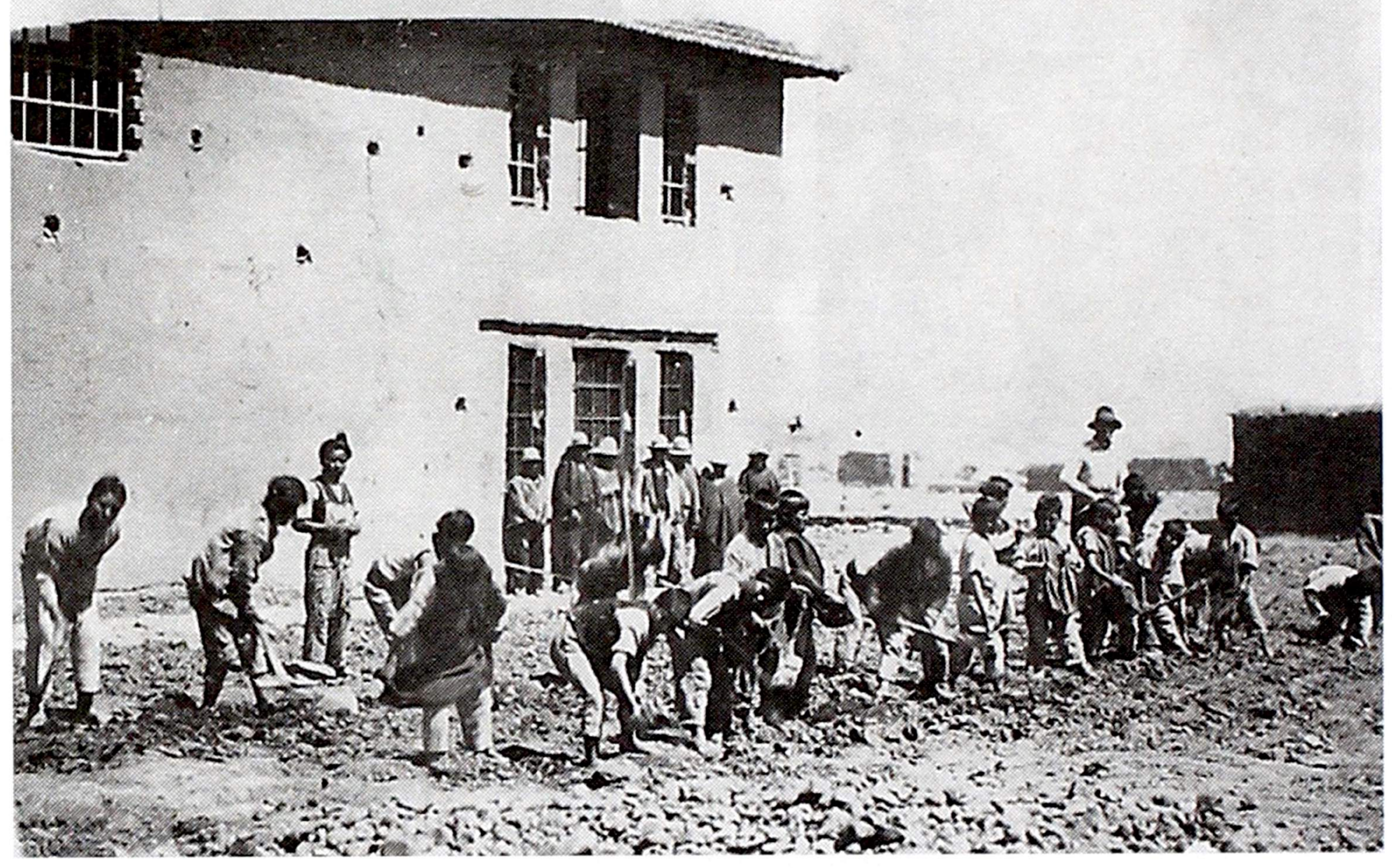

La escuela del trabajo (1932)

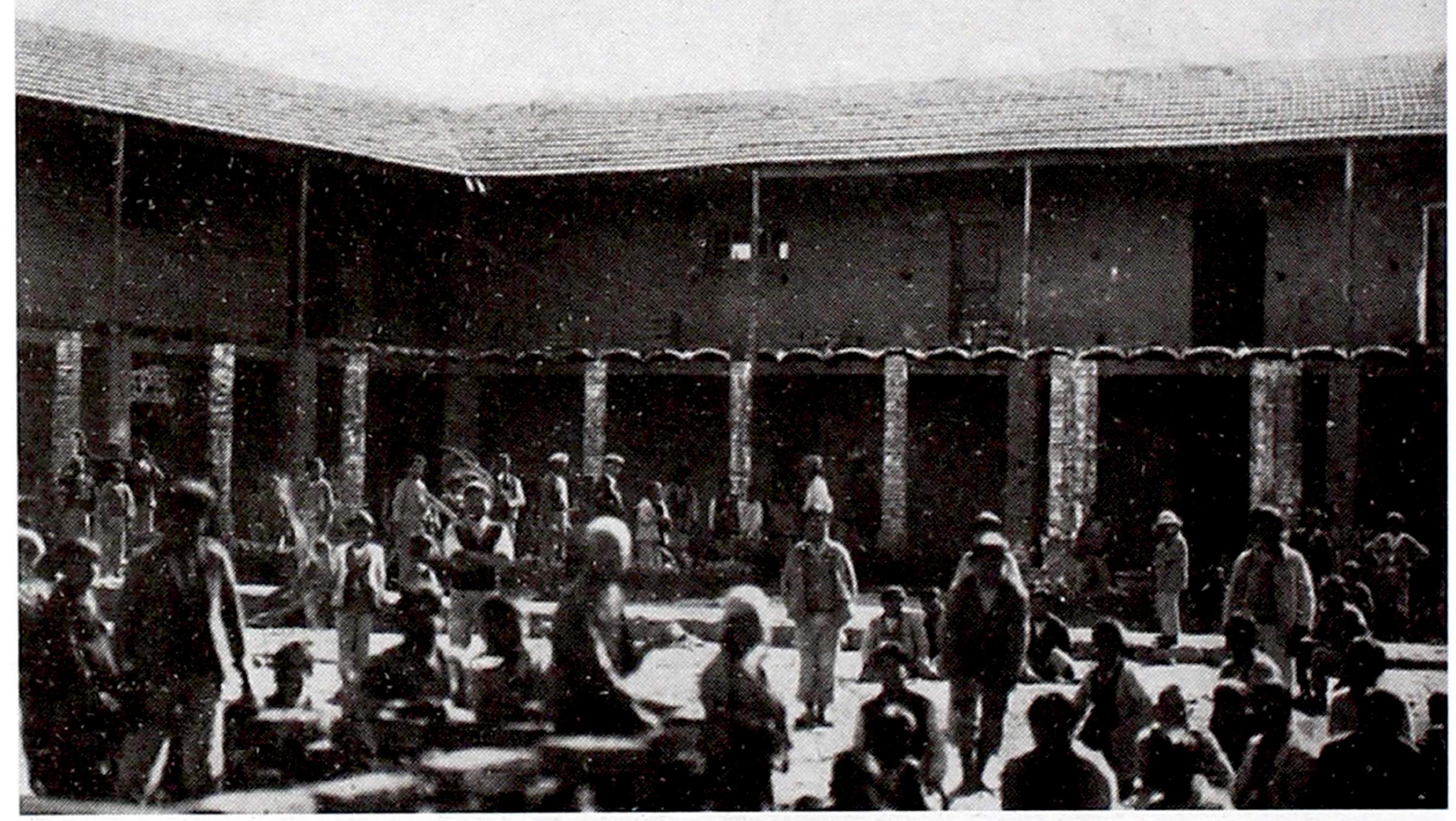

La escuela del trabajo (1932) 
Murales de Illanes en la Escuela-Ayllu de Warisata
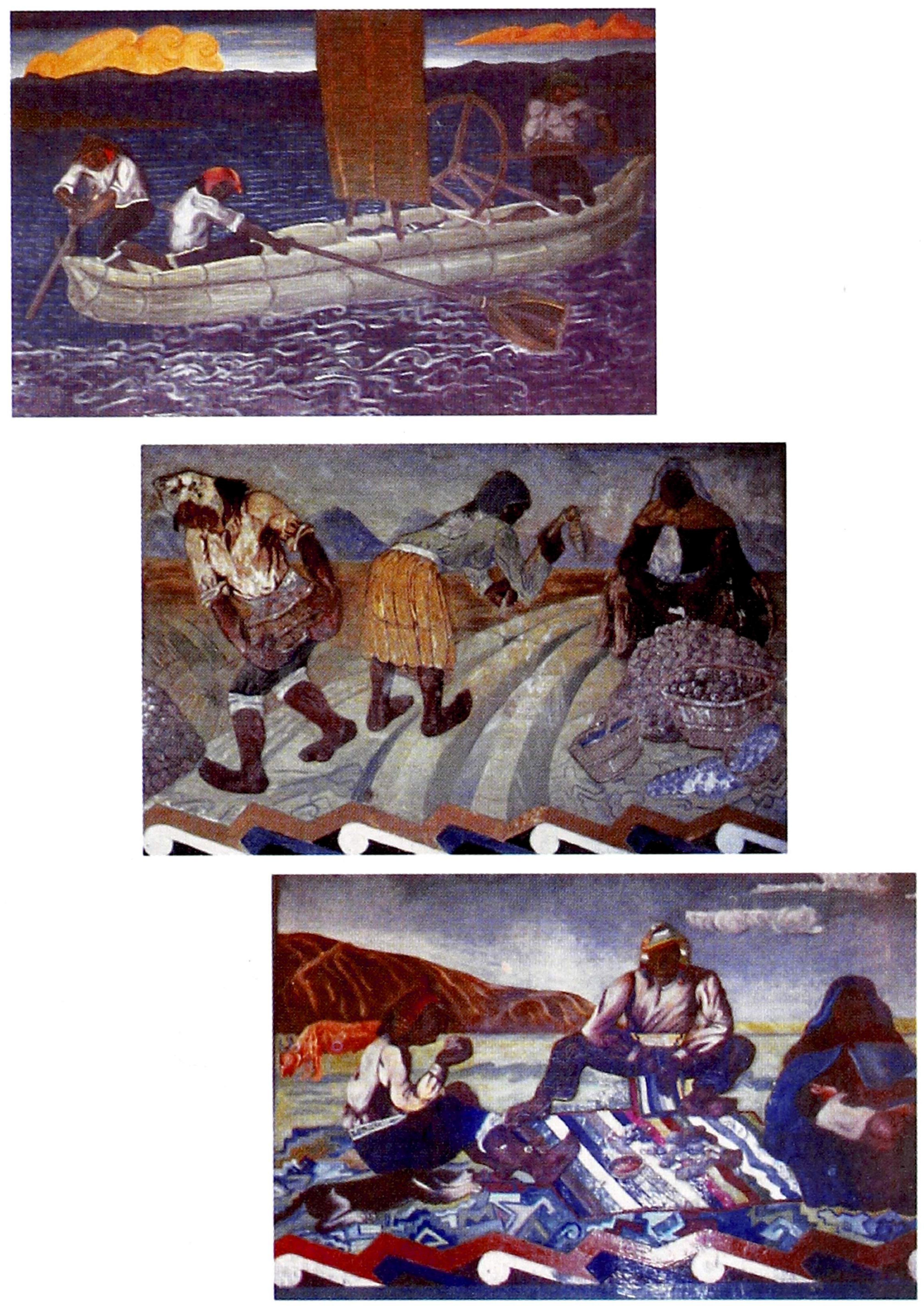


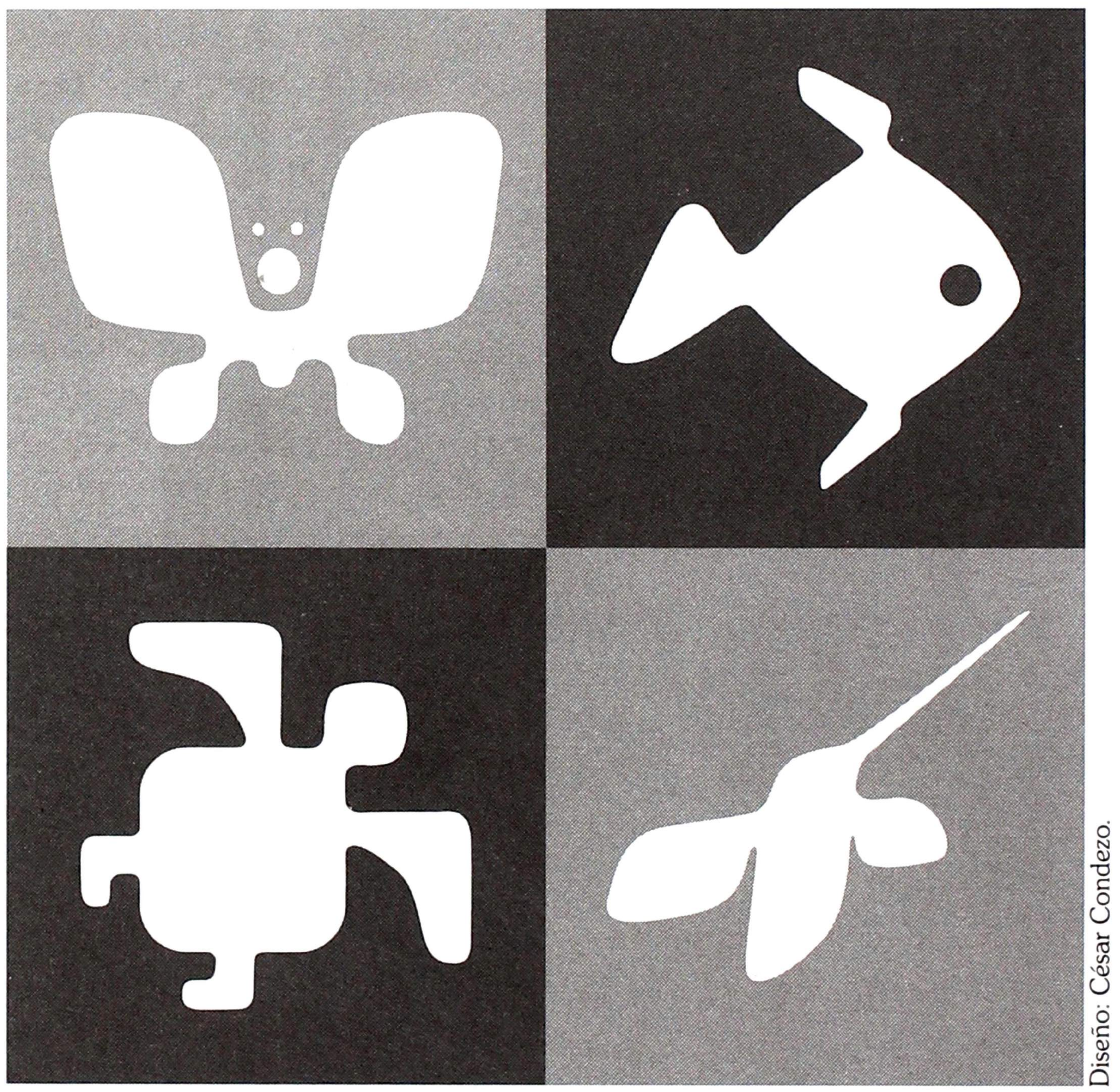

